Thls neport was prepared as an account of Government sponsored work, Nelther the Unfted states, nor the commsson, nor any person acting on behalf of the commission:

A. Makes any warranty or representation, expressed or $1 \mathrm{mpl}$ led, Wth respect to the accuracy, completeness, or usefulness of the Information contalned in this report, or that the use of any information, apparatus method, on process disclosed In this report may not Infringe privately owned rights; on

B. Assumes any liabilities with respect to the use of or for damags resulting from the use of any information, apparatus, method, or process disclosed in this report.

As used $1 \mathrm{n}$ the above, "person actlng on behalf of the commiss lon" Includes any employee or contractor of the Commiss lon, or employee of such contractor, to the extent that such employee or contractor of the comisston, or employee of such contractor prepanes, dlsseminates, or provides access to, any lnformation pursuant to his employment on contract with the comission, or his employment with such contractor.

Printed 1n USA. Price $\$ 0.35$

Avaliable from the U. S. Atomic Energy Commlssion Technical Information Service Extenston

P. 0. Box 1001, Oak Rlage, Tennessee

Please direct to the same address inquirles covering the procurement of other classifled AEG reports. 


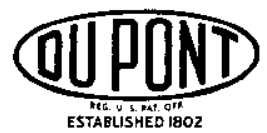

E. I. du Pont de Nemours \& Company INCORPORATED

Aiken, South Carolina

(TEl. \& TEL. ADdREss, Augusta, GA.)

EXPLOSIVES DEPARTMENT

SAVANNAH RIVER LABORATORY

H. WORTHINGTON, DIRECTOR TECHNICAL DIVISION - AED EXPLOSIVES DEPARTMENT WILMINGTON

\section{NOV 141962}

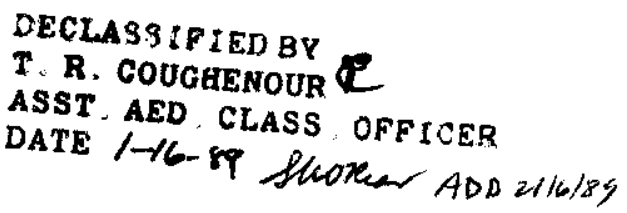

DP-741, PURIFICATION OF NEPTUNIUM RECOVERED FROM PUREX WASTE

by G. A. Burney and C. A. Prohaska

The attached report describes the laboratory demonstration of the process that is presently operated in Bullding 221-F to purify neptunium recovered from the high activity waste concentrate of the Purex process. This ion exchange process is operated in the frame designated as Frame IIF.

Our primary concern during the development of the process was to achieve adequate separation from fission products and to demonstrate a satisfactory operation of the cation exchange cycle for the removal of thorlum. As a result, the emphasis in the studies described in this report was on the behavior of fission products in tests with actual plant solutions and on the performance of the cation exchange cycle. After the successful laboratory demonstration of the process, it was expected that no unusual problems would be encountered in the plant process.

Contrary to expectations, serious difficulties developed in the early stages of operation in the Plant. The difficulties were completely unexpected because they were associated with the elution of neptunium from the anion resin. It appeared that neptunium was retained on the resin under conditions that should have given complete elution. Because this incomplete elution could not be duplicated in the laboratory with actual plant solutions, it was not possible to identify the cause of the apparent incomplete elution. Following

\section{UNCLASSIFIED}

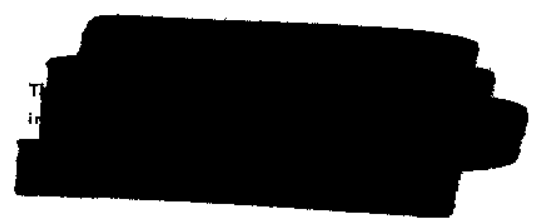

DOES NOT CONTAIN UNCLASSIFIED CONTROLLED NUCLEAR INFQRMATION

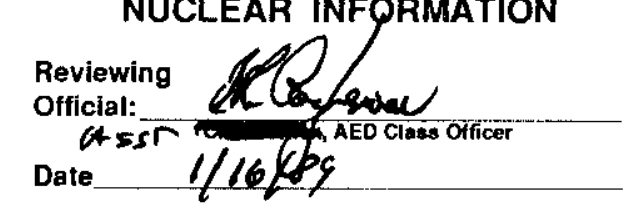

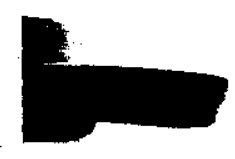




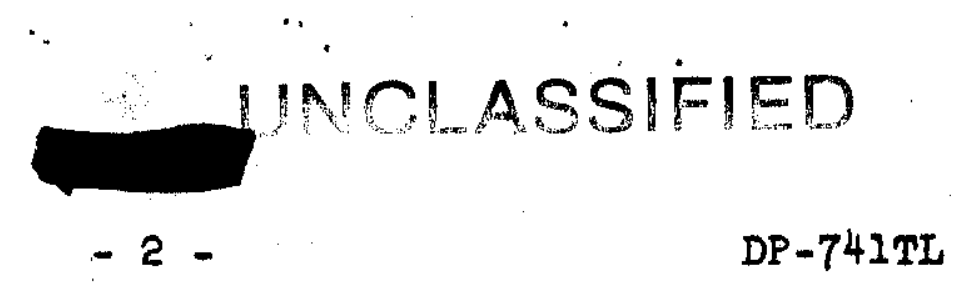

careful evaluation of operations in the Plant and some changes in procedures, successful performance of the ent1re process was achieved. The cause of the original difficulty was not established.

Excellent separation from fission products has been achleved, and the neptunium product has been well within the specifications for gamma activity. The thorlum content of the product has been well below the specifled IIm1t. The recovery of neptuntum has been somewhat errat1c, but in general has been above 95\%. Any unusualiy high losses are recycled for recovery.

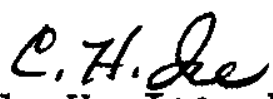

C. H. Ice, Research Manager

Separations Chemistry Division 


\section{INOALSSIFITD}

\section{INTERNAL DISTRIBUTION}

Copy No.

1-3. P. J. Hagelston

4. L. Squires - M. H. Wahl

5. S. A. McNeight

6. M. H. Smith - W. H. Holstein J. B. Tinker

7. I. C. Evans - H. Worthington C. W. J. Wende

8. V. R. Thayer

9. W File

10. A. D. Duff, Jr.

11. J. A. Monier - F. H. Endorf

12. W. P. Bebbington

13. E. B. Sheldon

14. R. I. Martens

15. R. L. Folger

16. A. W. Joyce

17. A. E. Wible - H. A. Strickland

18. W. L. Poe

19. PRD File

20. W. P. Overbeck - J.W. Croach

21. J. O. Morrison

22. J. E. Beach

23. J.W. Morris

24. C. H. Ice

25. D. S. Webster

26. H. J. Groh

27. W. J. Mottel

28. D. G. Karraker

29. G. A. Burney

30. C. A. Prohaska

31. TIS File Record Copy
SROO, Alken, S. C.

Wilmington AED

11

11

11

11

Engineering Department

Savannah River Plant

$$
\begin{aligned}
& 11 \\
& 11 \\
& 11 \\
& 11 \\
& 11 \\
& 11 \\
& 11
\end{aligned}
$$

Savannah River Laboratory 
NUCLEAR TECHNOLOGY - CHEMISTRY

Un AND CHEMICAL ENGINEERING (M-3679, 26th Ed.)

This document consists of $\frac{19}{233}$ Cages, Number 27 of

PURIFICATION OF NEPTUNIUM RECOVERED FROM PUREX WASTE

by

Glenn A. Burney and Charles A. Prohaska

September 1962

CLASSIFICATION CANCELLED
IOR CHANGED

DOES NOT CONTAN

UNCLASSIFIED CONTROLLA

NUCLEAR PNFORMATION

novowing Mloughereer 1-16-89

i A. Coughenour, ABst. AED Cles Critem
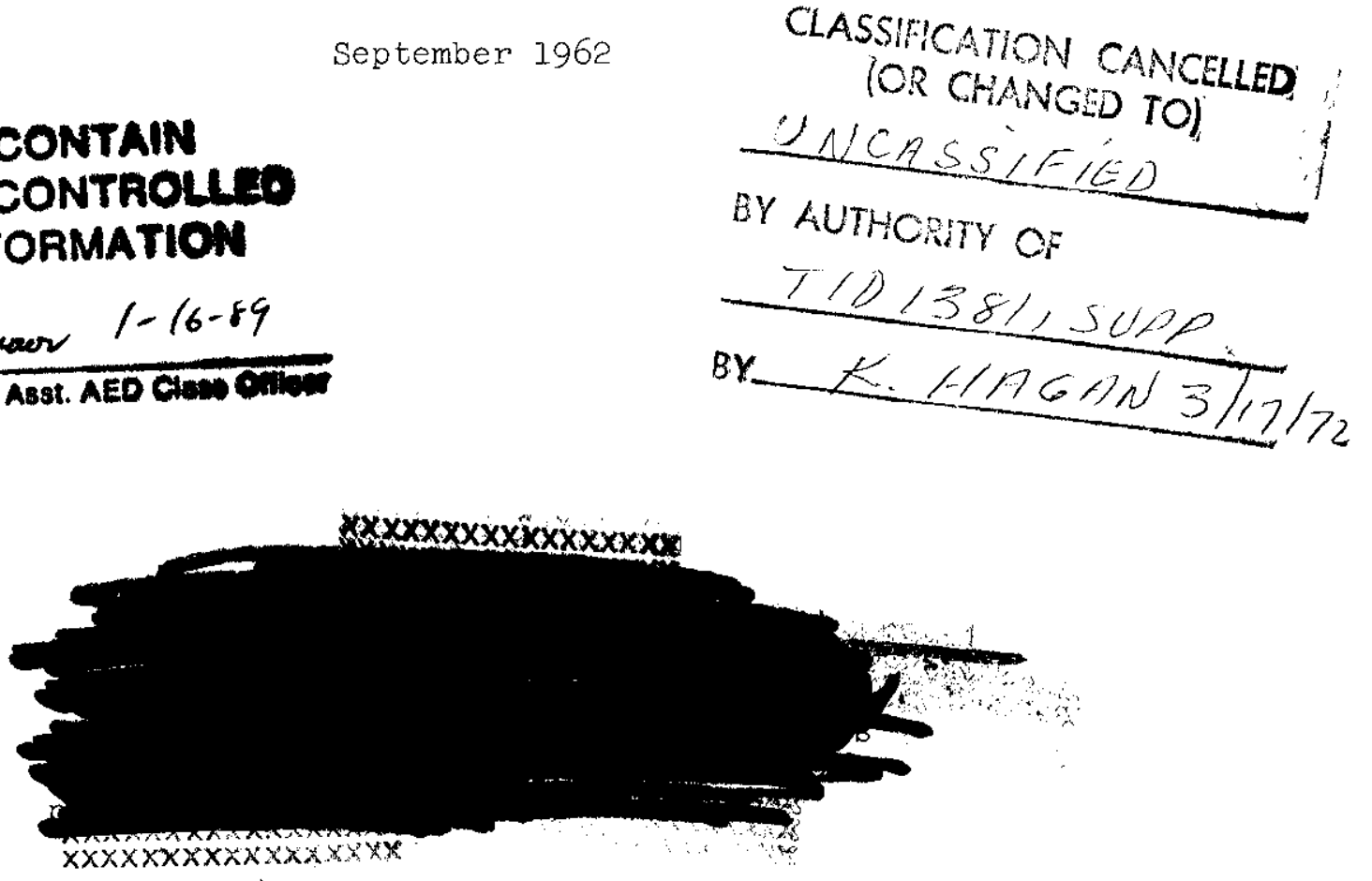

E. I. du Pont de Nemours \& Co.

Explosives Department - Atomic Energy Division

Technical Division - Savannah River Laboratory

Alken, South Carolina

Contract $\mathrm{AT}(07-2)-1$ with the

United States Atomic Energy Commission

Approved by

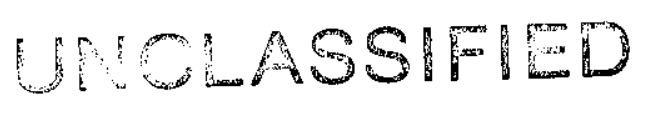

C. H. Ice, Research Manager

Separations Chemistry Division

OECASStht

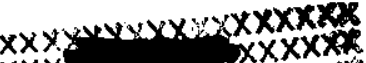
$x \times x \quad-x \times x \times x \times x$ $x \times x \times x \times \times$. $x \times x \times x \times x \times x \times x \times \times \times \times x$ 


\title{
LINCLASSIFIED
}

\begin{abstract}
An Ion exchange process was demonstrated to be satisfactory for the purification of $\mathrm{Np}^{237}$ recovered from Purex process wastes at Savannah River Plant. Two cycles of anion exchange and one cycle of cation exchange gave the required separation from the major impurities - plutonium, thorlum, and the fission products.
\end{abstract}




\section{WLASSIFIED}

DISTRIBUTION - SERIES A

Copy No.

1-3. AEC, SROO

4-46. Du Pont Company, Atomic Energy Division

47. Aerojet-General Corporation

48-49. Aerojet-General Nucleonics

50-55. Aeronautical Systems Division

56. A1r Defense Command

57-58. AlResearch Manufacturlng Company, Phoen1x

59-60. A1r Force Special Weapons Center

61-62. Albuquerque Operations office

63. Allied Chemical Corporation

64. Allis-Chalmers Manufacturirg Company

65. Allis-Chalmers Manufacturing Company, Washington

66. Allison Division-GMC

67-68. Argonne National Laboratory

69. Armour Research Foundation

70. Army Chemical Research and Development Laboratories

71-74. Atomic Energy Commission, Washington

75. Atomic Power Development Associates, Inc.

76-77. Atomics International

78. Avco Corporation

79-80. Babcock and Wilcox Company

81. Battelie Memorlal Institute

82. Bridgeport Brass Company

83. Bridgeport Brass Company, Ashtabula

84. Brookhaven National Laboratory

85. Bureau of Medicine and Surgery

86. Bureau of Mines, Salt Lake City

87-88. Bureau of Naval Weapons

89. Bureau of Ships

90. Chicago Patent Group

91. Columbla University (NYOO-187)

92. Combustion Englneering, Ine.

93. Combustion Engineering, Inc. (NRD)

94. Continental Army Command

95. Denver Research Institute

96. Director of Defense Research and Eng1neering (OSD)

97. Division of International Affairs, Tokyo

98. Dow Chemical Company (Rocky Flats)

99. Edgerton, Germeshausen and Grier, Inc., Goleta

100. Edgerton, Germeshausen and Grier, Inc., Las Vegas

101. Forelgn Technical Division AFSC

102. Franklin Institute of Pennsylvania

103. General Atomic Division

104. General Dynamics/Astronautics AF

105. General Dynamics/Fort Worth

106-108. General Electric Company, Cincinnati

109-112. General Electric Company, Richland

113. General Electric Company, San Jose

114. General Electric Company, St. Petersburg

115. General Nuclear Engineering Corporation

116. Gibbs and Cox, Inc.

117-118. Goodyear Atom1c Corporation

119. Hanford Operations office

120. Iowa State University

121. Jet Propulsion Laboratory

122-123. Knolls Atomic Power Laboratory

124. Lockheed Missiles and Space Company 
Copy No.

125-126. Los Alamos Sclentific Laboratory

127. Mallinckrodt Chemical Works

128. Marquardt Corporation

129. Martin-Marletta Corporation

130. Martin-Marietta Corporation, Denver

131. Massachusetts Inst1tute of. Technology (Evans)

132. Mound Laboratory

133. NASA Lew1s Research Center

134. NASA Marshall Space Flight Center

135-137. NASA Scientific and Technical Information Facility

138. National Bureau of Standards

139. National Lead Company of Ohio

140. Naval Air Materlal Center

141. Naval Engineering Experiment Station

142. Naval Medical Research Institute

143. Naval Postgraduate School

144. Naval Rad1ological Defense Laboratory

145. Naval Research Laboratory

146. Naval Weapons Laboratory

147. New Brunswick Area Office

148. New York Naval Shipyard

149. New York Operations Office

150. New York Operations office, Canel Division

151. Nuclear Materials and Equipment Corporation

152. Nuclear Metals, Inc.

153. Nuclear Weapons Training Center Atlantic

154. Oak R1dge Operations office

155. Office of the Assistant General Counsel for Patents (AEC)

156. Offlce of Naval Research

157. Office of the Chief of Naval Operations

158-161. Phill1ps Petroleum Company (NRTS)

162. Pinellas Area Office

163. Pratt and Whitney Alrcraft Division

164. Public Health Service

165. Rand Corporation

166. San Franc1sco Operations office

167. Sandia Corporation

168. Sandia Corporation, Livermore

169. Surgeon General

170. Tennessee Valley Authorlty

171. Tracerlab, Inc., Richmond

172-174. Union Carbide Nuclear Company (ORGDP)

175-179. Union Carbide Nuclear Company (ORNL)

180. Union Carbide Nuclear Company (Paducah Plant)

181. United Nuclear Corporation (NDA)

182. Un1ted Nuclear Corporation (OMC)

183-184. University of Cal1forn1a, Berkeley

185-186. University of California, Livermore

187. University of California, Los Angeles

188. University of Washington

189-190. Westinghouse Bett1s Atom1c Power Laboratory

191. Westinghouse Electric Corporation

192. Westinghouse Electric Corporation (NASA)

193. Yankee Atomic Electric Company (NYOO-222)

194-233. Division of Technical Information Extension

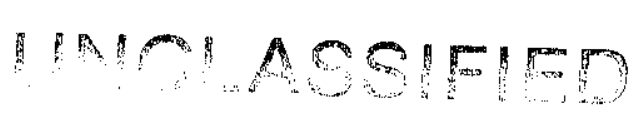




\section{IINAI ASSIFIEN}

\section{CONTENTS}

$\underline{\text { Page }}$

List of Tables and Figures 6

Introduction 7

Summary 7

Discussion 8

Experimental 9

Description of AnIon Exchange Cycles 9

Performance of An1on Exchange Cycles II

Thorium Separation by Cation Exchange Cycle 12

Over-all Performance of Process 16

Bibliography 17

\section{liarl Aacigin}

$-5-$ 
$1 M P A \operatorname{Com} M$

LIST OF. TABLES AND FIGURES

Table

$\underline{\text { Page }}$

I Composition of Feed to Purfication Process 8

II Performance of Anion Exchange Cycles 11

III Oxidation of $\mathrm{Np}(\mathrm{IV})$ to $\mathrm{Np}(\mathrm{V}) \quad 12$

IV Performance of Cation Exchange Cycle 15

Figure

1 Flowsheet 10

2 Effect of Flow on Absorption of Thorium by Cation Resin

3 Effect of Thorlum Concentration on Absorption of Thorium by Cation Resin

7 Elution of $T h(I V)$ from Cation Resin with Nitric Acid 


\section{PURIFICATION OF NEPTUNIUM RECOVERED FROM PUREX WASTE \\ INTRODUCTION}

$\mathrm{Np}^{237}$ is produced as a byproduct when natural uranium is irradiated with neutrons to produce $\mathrm{Pu}^{239}$. The neptunium is present at levels of 2 to $4 \mathrm{ppm}$ in the irradiated uranium after normal reactor exposure. In the Purex solvent extraction process for the recovery and purification of uranium and plutonium, the neptunium is diverted primarily to the high activity aqueous waste stream from the first solvent extraction contactor. The recovery of neptunium from the concentrated waste, by a single cycle of anion exchange on an agltated bed of resin, is described in another report ${ }^{(1)}$.

The product from the recovery step is a dilute solution of neptunium in nitric acid, free of gross amounts of fission products. A process was required to purify the neptunium further and to recover it in high yield. The major contaminants anticipated were $\mathrm{Pu}^{239}, \mathrm{Th}^{232}, \mathrm{Th}^{234}$, $\mathrm{Zr}^{95}$, $\mathrm{Nb}^{95}$, $\mathrm{Ru}^{103}$, and $\mathrm{Ru}^{106}$. It was necessary that the process be operable in remote ion exchange equipment of the type that has been previously described. (2)

Sufflclent data were already avallable on the anion exchange behavior of neptunium $(3,4,5,6)$ to indicate that the required separation from plutonium and fission products could be obtained in two repetitive anion exchange cycles in which the anionic nitrate complex of $\mathrm{Np}$ (IV) was absorbed. In addition, information was avallable to indicate that the required separation from thorium could be obtained by cation exchange absorption of $\mathrm{Th}(\mathrm{IV})$ in the presence of the weakly absorbed $\mathrm{NpO}_{2}^{+}$. This report describes the laboratory tests of a proposed purification process consisting of two fixed-bed anion exchange cycles followed by one fixed-bed cation cycle. Particular attention was given to evaluating the purity and the yield of neptunium attainable in this process.

\section{SUMMARY}

A process was demonstrated for the purification of neptunium recovered from the high activity waste concentrate of the Purex process at the Savannah River Plant. The major impurities to be removed in the process were $\mathrm{Pu}^{239}, \mathrm{Th}^{232}$, $\mathrm{Th}^{234}, \mathrm{Ru}^{103}, \mathrm{Ru}^{106}, \mathrm{Zr}^{95}$, and $\mathrm{Nb}^{95}$. Plutonium and the fission products were separated from the neptunium by two cycles of anion exchange from a concentrated nitrate solution, and thorium was separated by a single cycle of cation exchange from a dilute nitrate solution.

In both anion exchange cycles, $\mathrm{Np}(\mathrm{IV}), \mathrm{Pu}(\mathrm{IV})$, and $\mathrm{Th}(\mathrm{IV})$ were absorbed on the resin as the anionic nitrate complexes. The fission products were washed from the resin with $8 \mathrm{M} \mathrm{HNO}_{3}-0.005 \mathrm{M} \mathrm{KF}$, and plutonium was removed by washing with $6 \mathrm{M} \mathrm{HNO}_{3}-0.05 \mathrm{M} \mathrm{N}_{2} \mathrm{H}_{4}-0.05 \mathrm{M} \mathrm{Fe}\left(\mathrm{NH}_{2} \mathrm{SO}_{3}\right)_{2}$. Finally, neptunium and thorium were eluted from the resin with dilute 


\section{UNCLASSIFIED}

nitric acid. In the cation exchange cycle neptunium was oxidized to weakly absorbable $\mathrm{NpO}_{2}^{+}$. The $\mathrm{NpO}_{2}^{+}$that was absorbed along with the thorium was washed from the resin with $I M \mathrm{HNO}_{3}$. Thorium was eluted from the resin with sodium bisulfate when the column was loaded to the point of breakthrough.

After the three cycles of 1on exchange, neptunium was separated from plutonium by a factor $>200$, from thorium by a factor $>170$, and from fission products by a factor $>1.5 \times 10^{5}$. The over-ali recovery of neptunium was greater than $96 \%$.

\section{DISCUSSION}

The concentrated high activity waste from the Purex process contains 10 to $20 \mathrm{mg} / \mathrm{l}$ of $\mathrm{Np}^{237}, 1$ to $20 \mathrm{mg} / 1$ each of $\mathrm{Pu}^{239}$ and $\mathrm{Th}^{232}$, and 100 to $1000 \gamma$ curles/l of fission product activity. Actual plant waste was processed in the laboratory to recover neptunium by a single cycle of anion exchange on an agitated bed of resin(1). The neptunium solution from this operation was then used in the demonstration of the purification process. A typical composition of the solution produced from the single cycle of anion exchange is shown in Table I.

\section{TABLE I}

\section{Composition of Feed to Purification Process}

\begin{tabular}{|c|c|}
\hline Constituent & Concentration \\
\hline Nitric acid & $2.2 \mathrm{M}$ \\
\hline Neptunium & $0.1-0.2 \mathrm{~g} / 1$ \\
\hline Plutonium & $0.1-0.2 \mathrm{~g} / 1$ \\
\hline Thortum & $<0.05 \mathrm{~g} / 1$ \\
\hline Fission products & $1-10 \gamma$ curles $/ 1$ \\
\hline
\end{tabular}

The specifications for the $\mathrm{Np}^{237}$ product from the purification process were:

$\begin{array}{ll}\text { Fission product activity } & <3 \times 10^{-4} \gamma \text { curies } / \mathrm{B} \text { Np } \\ \text { Plutonium } & <1 \text { wt } \% \\ \text { Thorium } & <1 \text { wt } \%\end{array}$

From these specifications and the composition of the feed solution it was estimated that separation from plutonium by a factor of 100 , from thorium by a factor of 50, and from fission products by a factor of $\sim 1.5 \times 10^{5}$ would be required in the three ion exchange cycles of the purification process. A further goal of the process was that neptunium should be recovered in yields greater than $95 \%$.

$$
\begin{aligned}
& -8- \\
& \text { PHA A C }
\end{aligned}
$$


Prior work $(3,4,5,7,8)$ has shown that $N p(I V), P u(I V)$, and $T h(I V)$ form anionic nitrate complexes that are strongly absorbed by anion resins from solutions 6 to $10 \mathrm{M}$ in total nitrate. Under these conditions the fission products are absorbed to only a very slight extent, and residual amounts may be washed from the resin with $8 \mathrm{M} \mathrm{HNO}_{3}$. Plutonium may be separated from neptunium and thorium by washing the resin with $6 \mathrm{M} \mathrm{HNO}_{3}$ containing ferrous sulfamate and hydrazine(6). Neptunium and thorium are eluted readily from the anion resin with dilute nitric acia.

A cation exchange cycle was designed to separate neptunium from thorium. In this cycle neptunium is present as the $\mathrm{NpO}_{2}^{+}$ion and is absorbed much less strongly than Th(IV). Because the condltions for this separation were not well defined, the various steps in the cycle were investigated to establish sultable conditions for the process.

\section{EXPERIMENTAL}

The initial studies of the process were made with solutions containing only neptunium, plutonium, and thorium, to establish the conditions required for adequate recovery of neptunium and for adequate separation from plutonium and thorium. A solution prepared from actual plant waste was used in the final demonstration of the process. The ion exchange columns used in the demonstration were 13 inches high and $0.62 \mathrm{~cm}^{2}$ in cross-sectional area. This height was approximately the same as that of the plant columns, and the area was about $1 / 1250$ of the plant columns. "Dowex" $1-\mathrm{X} 3$ and $1-\mathrm{X} 4$, 40-60 mesh anion resins and "Dowex" 50 -X8 cation resin were used in the tests. The resins were washed with nitric acid to convert the anion resin to the nitrate form and the cation resin to the hydrogen form. This wash also removed iron from the cation resin.

Ferrous sulfamate was prepared by dissolving iron powder in a slight excess of sulfamic acid. The stock solution of hydrazine was either a $3 \mathrm{M}$ aqueous solution of hydrazine nitrate from the Falrmount chemical Co., Inc. or "Hyzeen", a $30 \%$ aqueous solution of hydrazine from the Betz Laboratories, Inc.

\section{DESCRIPTION OF ANION EXCHANGE CYCLES}

The crude neptunium recovered from the concentrated waste of the Purex process was processed through three cycles of fixed-bed lon exchange for purification (Figure 1). Two cycles of anion exchange were required for removal of plutonium and fission products. These cycles differed only in the order of the wash steps. The feed was adjusted to $8 \mathrm{M} \mathrm{HNO}_{3}$ and ferrous sulfamate was added; $\mathrm{Np}$ (IV) and $\mathrm{Pu}$ (III) were produced almost instantaneousiy. The solution was then heated to $55^{\circ} \mathrm{C}$ for 30 minutes to oxidize the excess $\mathrm{Fe}$ (II) to $\mathrm{Fe}$ (III) and the $\mathrm{Pu}(\mathrm{III})$ to $\mathrm{Pu}(\mathrm{IV})$. The anionic nitrate complexes of $\mathrm{Np}(\mathrm{IV}), \mathrm{Pu}(\mathrm{IV})$, and $\mathrm{Th}(\mathrm{IV})$ formed in solution were absorbed on the anion resin, and the resin was washed with 10 to 20 bed volumes of $8 \mathrm{M} \mathrm{HNO}_{3}-0.005 \mathrm{M} \mathrm{KF}$ to remove the fission products. Plutonium was washed from the resin with 15 bed volumes of $6 \mathrm{M} \mathrm{HNO}_{3}-0.05 \mathrm{M} \mathrm{N}_{2} \mathrm{H}_{4}-0.05 \mathrm{M} \mathrm{Fe}\left(\mathrm{NH}_{2} \mathrm{SO}_{3}\right)_{2}$; this wash removed 85 to $100 \%$

\section{inin AssIFIEn}




\section{UNCLASSIFIED}

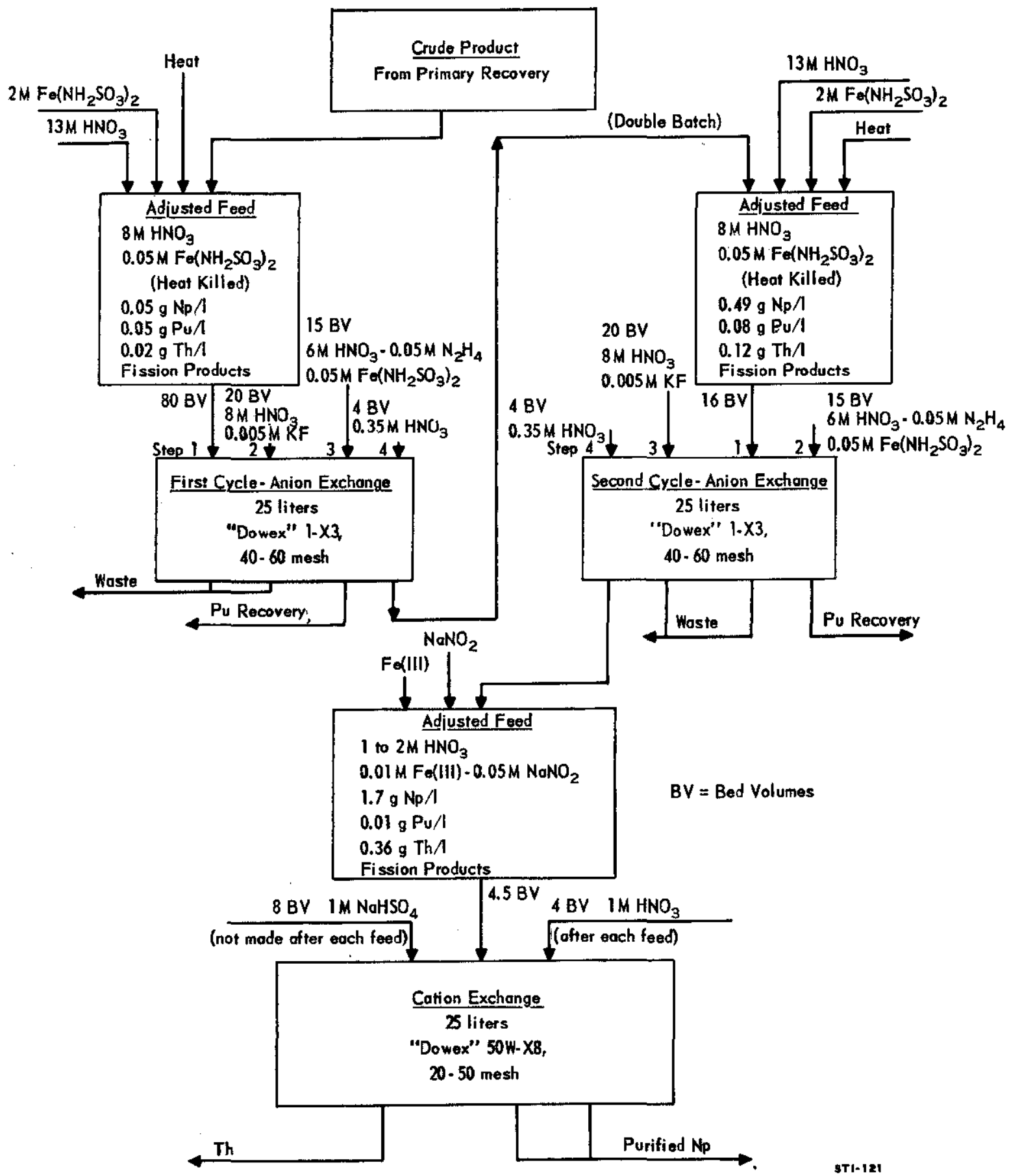

FIG. 1 FLOWSHEET 
of the plutonium. In the second anion exchange cycle the loaded resin was washed first to remove plutonium and then to remove fission products. The wash steps were reversed even though the removal of fission products was somewhat less effective with this sequence, because the presence of hydrazine in the neptunium product solution from this cycle would interfere with the adjustment of the valence of neptunium in the following cation exchange cycle.

The process was designed so that plutonium that was separated from neptunium in the anion exchange cycles could be returned to the second cycle of the Purex process.

\section{PERFORMANCE OF ANION EXCHANGE CYCLES}

Laboratory tests with "Dowex" 1-X4, 40-60 mesh resin demonstrated the necessity for two cycles of anion exchange on flxed beds of resin. Two cycles were necessary to attain adequate separation of plutonium when the $\mathrm{Np} / \mathrm{Pu}$ ratio was less than 3 or $4^{(6)}$; they were also required to ensure adequate removal of fission products. When "Dowex" $1-X 3$, 40-60 mesh resin was used, only one cycle was required to separate plutonium even with $\mathrm{Np} / \mathrm{Pu}$ ratios as low as 0.2 ; however, two cycles were required to remove fission products.

The results given in Table II are typical of those obtained with feed solutions prepared from actual plant waste. These results show that both the recovery and purification of neptunium were quite adequate in the two anion exchange cycles.

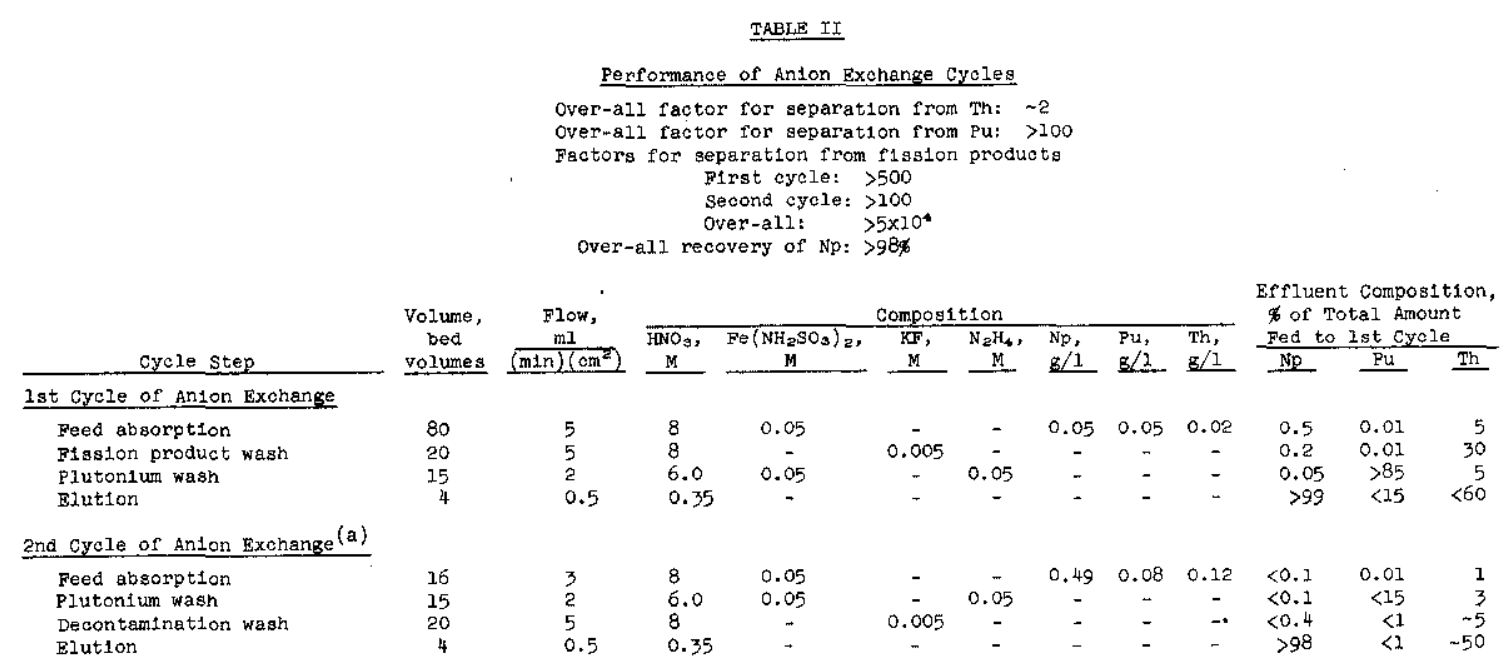

(a) The products from two first cycle mus were comblned for processing through the second oycle.

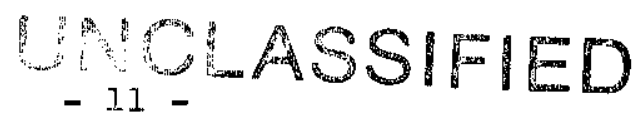




\section{UNCLASSIFIED}

\section{THORIUM SEPARATION BY CATION EXCHANGE CYCLE}

The separation of thorium and neptunium and further purification of neptunlum from fission products was accomplished in the cation exchange cycle with "Dowex" 50W-X8 resin. Neptunium in the 1 to $2 \mathrm{M} \mathrm{HNO}_{3}$ solution from the second anion exchange cycle was oxidized to $\mathrm{Np}(\mathrm{V})$. The $\mathrm{NpO}_{2}^{+}$ Ion was absorbed only weakly by the cation resin, while the Th(IV) was strongly absorbed. Fe(III) was added to the feed to increase the rate of oxidation and to complete conversion of $\mathrm{Np}$ (IV) to $\mathrm{Np}$ (V) when the solution was heated to $70^{\circ} \mathrm{C}$. The effect of $\mathrm{Fe}$ (III) on the oxidation of $\mathrm{Np}$ (IV) is shown by the data in Table III.

TABLE III

Oxidation of $\mathrm{Np}(\mathrm{IV})$ to $\mathrm{Np}(\mathrm{V})$

\begin{tabular}{|c|c|c|c|}
\hline Composition of solution & $\begin{array}{l}\text { Temp, } \\
{ }^{\circ} \mathrm{C} \\
\end{array}$ & $\begin{array}{l}\text { Time, } \\
\mathrm{hr}\end{array}$ & $\begin{array}{c}\mathrm{Np}(\mathrm{IV}) \\
\text { Oxidized, }\end{array}$ \\
\hline $2 \mathrm{M} \mathrm{HNO}_{3}-18 \mathrm{~Np} / 1$ & 23 & 24 & $<5^{(a)}$ \\
\hline $2 \mathrm{M} \mathrm{HNO} 3-1 \mathrm{~g} \mathrm{Np/1}$ & 70 & 0.5 & $10-50(a)$ \\
\hline $2 \mathrm{MHNO}_{3}-0.05 \mathrm{M} \mathrm{NaNO}=1 \mathrm{~g} \mathrm{~Np} / 1$ & 23 & 0.5 & $<5^{(a)}$ \\
\hline $2 \mathrm{MHNO} 3-0.05 \mathrm{M} \mathrm{NaNO}=-I g \mathrm{~Np} / 1$ & 70 & 0.5 & $<25(a)$ \\
\hline $1 \mathrm{M} \mathrm{HNO}{ }_{3}-0.01 \mathrm{M} \mathrm{Fe}(I I I)-1 \mathrm{~g} \mathrm{~Np} / 1$ & 23 & 5 & $>98$ \\
\hline $1 \mathrm{MHNO} 3-0.01 \mathrm{M} \mathrm{Fe}(\mathrm{III})-1 \mathrm{~g} \mathrm{~Np} / \mathrm{I}$ & 70 & $<0.5$ & $>98$ \\
\hline $2 \mathrm{~N} \mathrm{HNO}_{3}-0.01 \mathrm{M} \mathrm{Fe}(\mathrm{III})-1 \mathrm{~g} \mathrm{~Np} / 1$ & 23 & 24 & $70-80$ \\
\hline $2 \mathrm{M} \mathrm{HNO}_{3}-0.01 \mathrm{M} \mathrm{Fe}$ (III) $-1 \mathrm{~g} \mathrm{~Np} / \mathrm{l}$ & 70 & $<0.5$ & $>98$ \\
\hline
\end{tabular}

(a) Observed oxidation possibly due to traces of $\mathrm{Fe}$ (III) or other cationic impurities.

Although sodium nitrite did not appreciably affect the rate of oxidation of $\mathrm{Np}(\mathrm{IV})$ to $\mathrm{Np}(\mathrm{V})$, it was added to the feed after cooling to stabilize $\mathrm{Np}(\mathrm{V})$ in the presence of the resin. In the absence of nitrite, approximately 5\% of the $\mathrm{Np}(\mathrm{V})$ was reduced to $\mathrm{Np}(\mathrm{IV})$ and was retained on the resin $\{\theta\}$ with the thorium. The addition of nitrite to the feed decreased the amount retained on the resin to 1 to $2 \%$.

"Dowex" 50W-X8, 20-50 mesh resin was used to obtain the desired hydraulic characteristics. The use of $20-50$ mesh resin limited the flow during the absorption step to $3 \mathrm{ml} /(\mathrm{min})\left(\mathrm{cm}^{2}\right)$ and the number of batches processed to 4 or 5 before the breakthrough of thorium occurred and elution was required (Figure 2). The volume of solution that could be processed before the breakthrough occurred decreased as the concentrations of thorium and nitric acid increased (Figures 3 and 4 ). The absorption flow was increased to $5 \mathrm{ml} /(\mathrm{min})\left(\mathrm{cm}^{2}\right)$ and the number of batches to 10 by using 50-100 mesh resin; however, hydraulic properties of the smaller resin particles were less favorable. The variation in particle size of resin did not alter the effectiveness of the separation of thorium from neptunium. 
MraAg Am

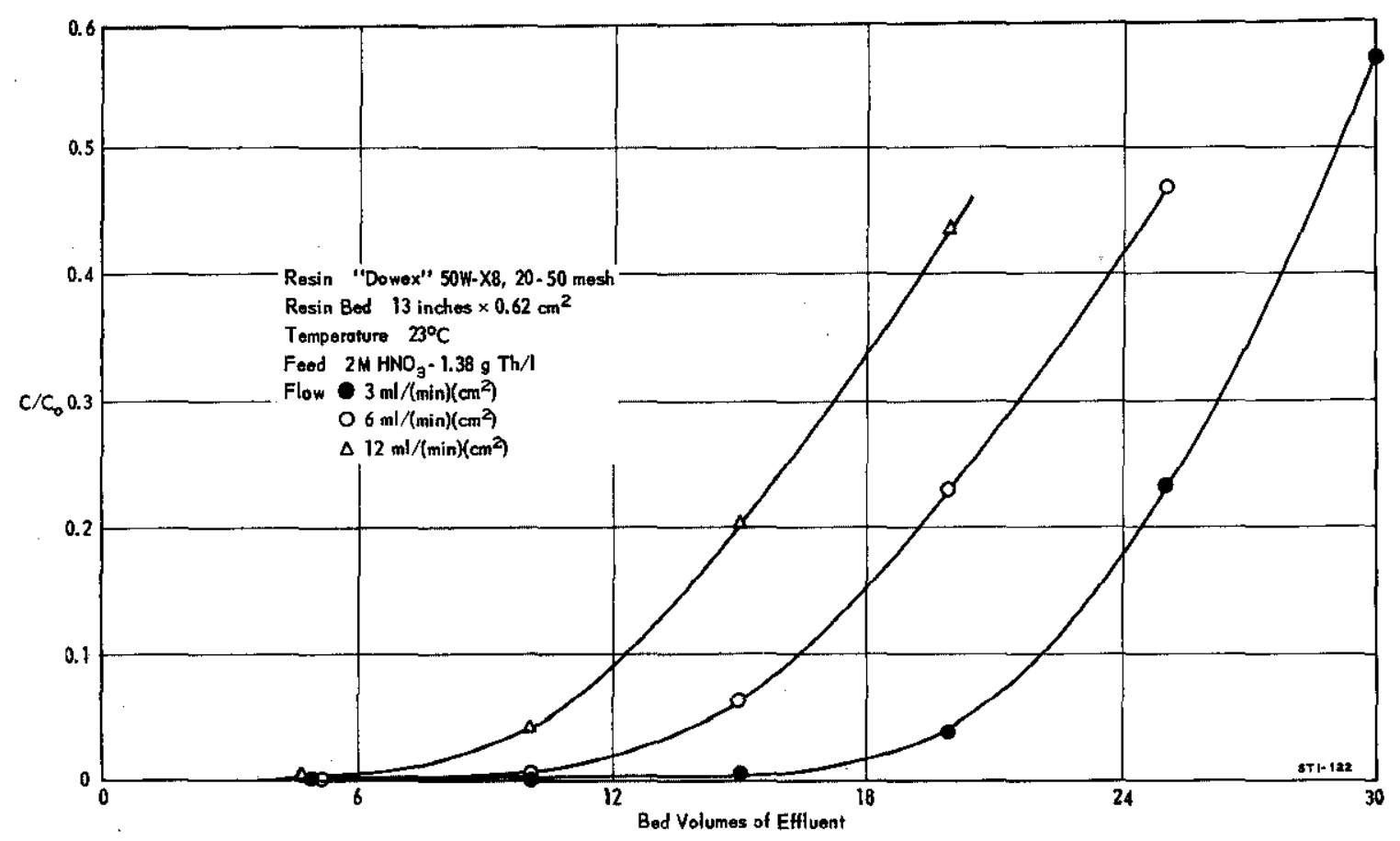

FIG. 2 EFFECT OF FLOW ON ABSORPTION OF THORIUM BY CATION RESIN

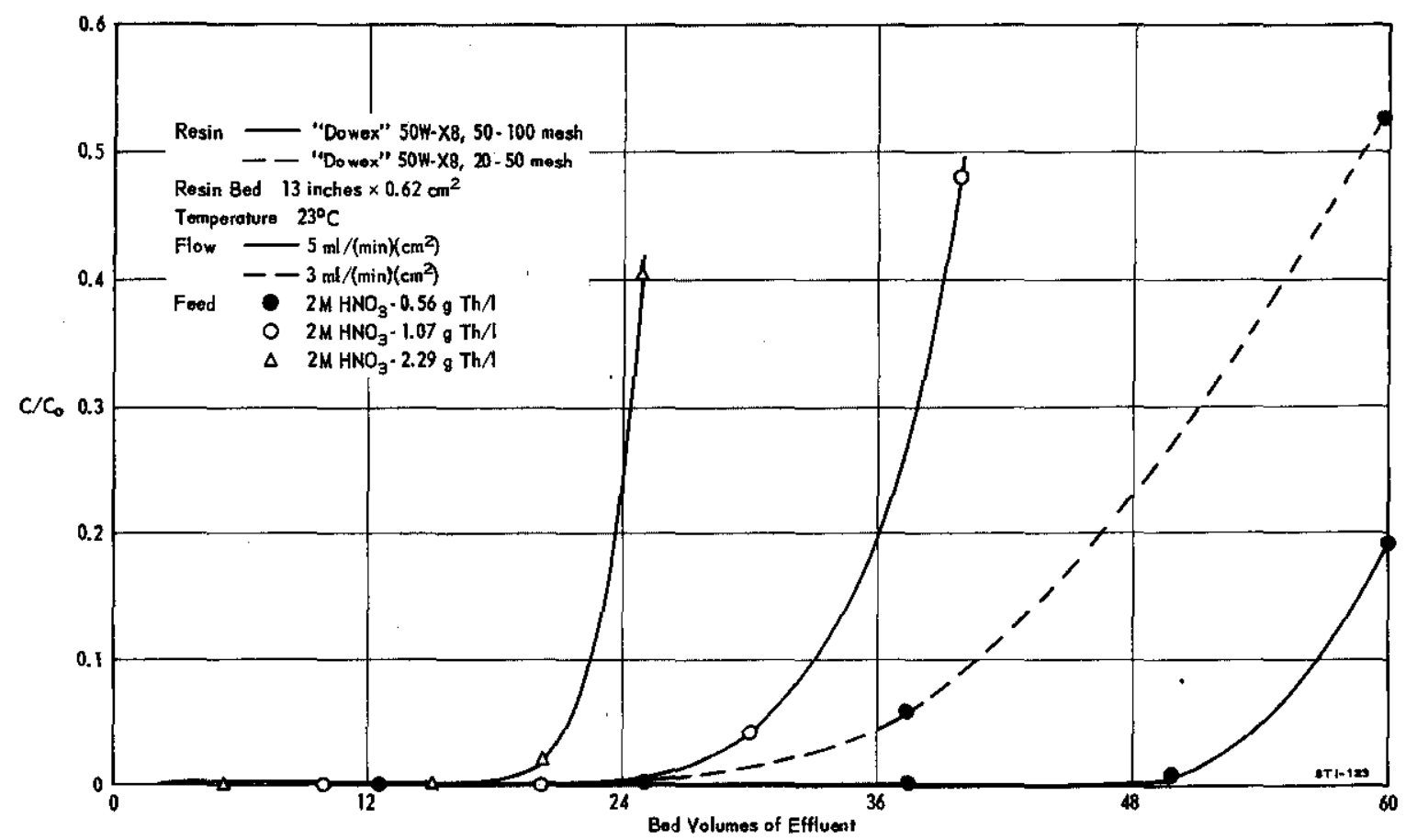

FIG. 3 EFFECT OF THORIUM CONCENTRATION ON ABSORPTION OF THORIUM BY CATION RESIN 


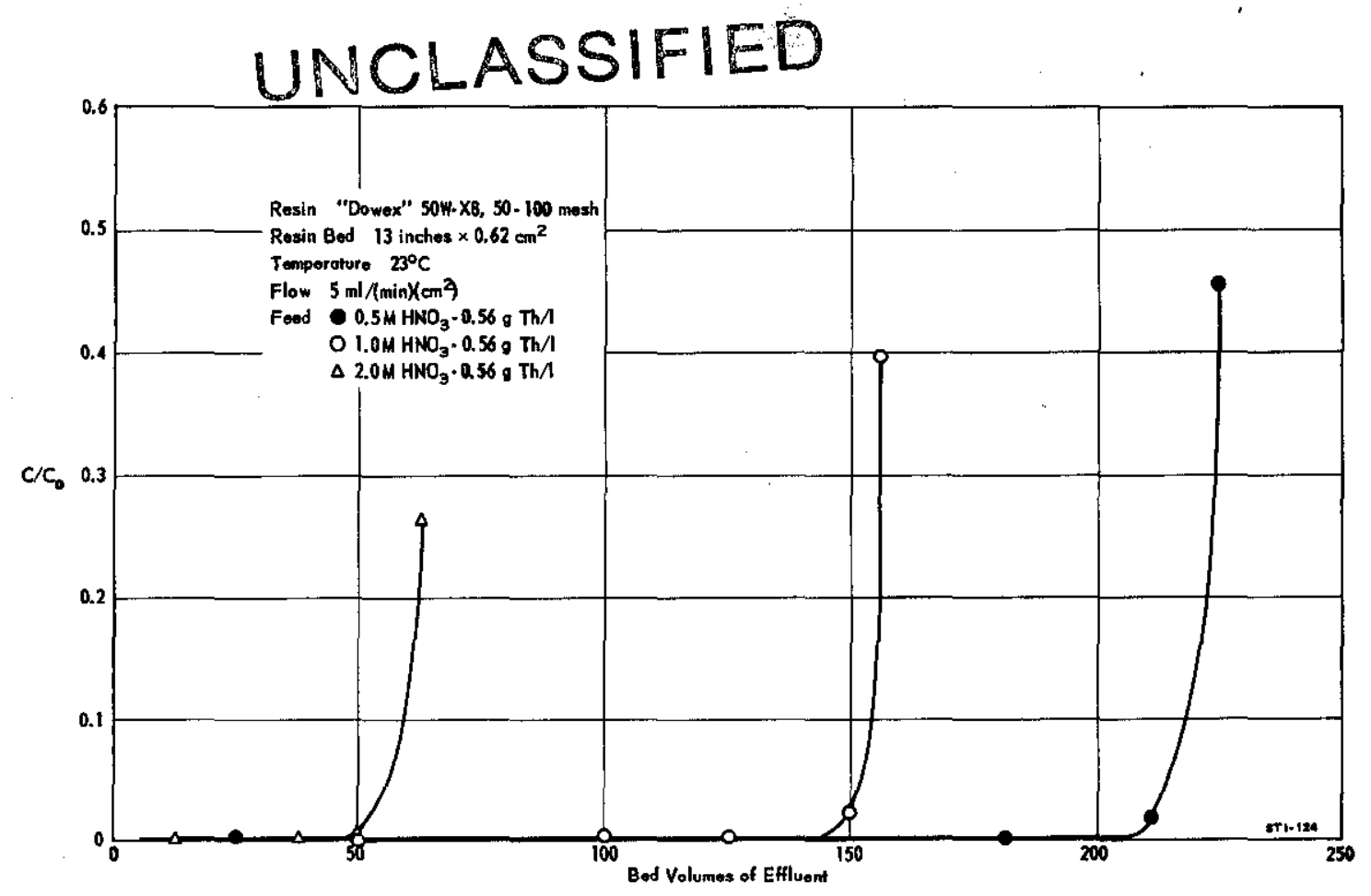

FIG. 4 EFFECT OF ACID CONCENTRATION ON ABSORPTION OF THORIUM BY CATION RESIN

At the completion of the absorption step approximately $25 \%$ of the $N p(V)$ was uniformly distributed over the resin, and the remainder was in the effluent (Figure 5). Immediately after passage of the feed, the resin was washed with 4 to 5 bed volumes of 0.5 to IM $\mathrm{HNO}_{3}$ to elute the neptunium because when $\mathrm{Np}(\mathrm{V})$ remalned in contact with the resin $1 t$ was reduced to $\mathrm{Np}(\mathrm{IV})$. Following this wash, only 1 to $2 \%$ of the neptunium remained on the resin. If the resin was not washed immediately but was allowed to stand for 72 hours, 25 to $50 \%$ of the neptunium on the resin was reduced to $\mathrm{Np}(\mathrm{IV})$ and was not removed by the wash $\mathrm{w} 1$ th $1 \mathrm{M} \mathrm{HNO}_{3}$.

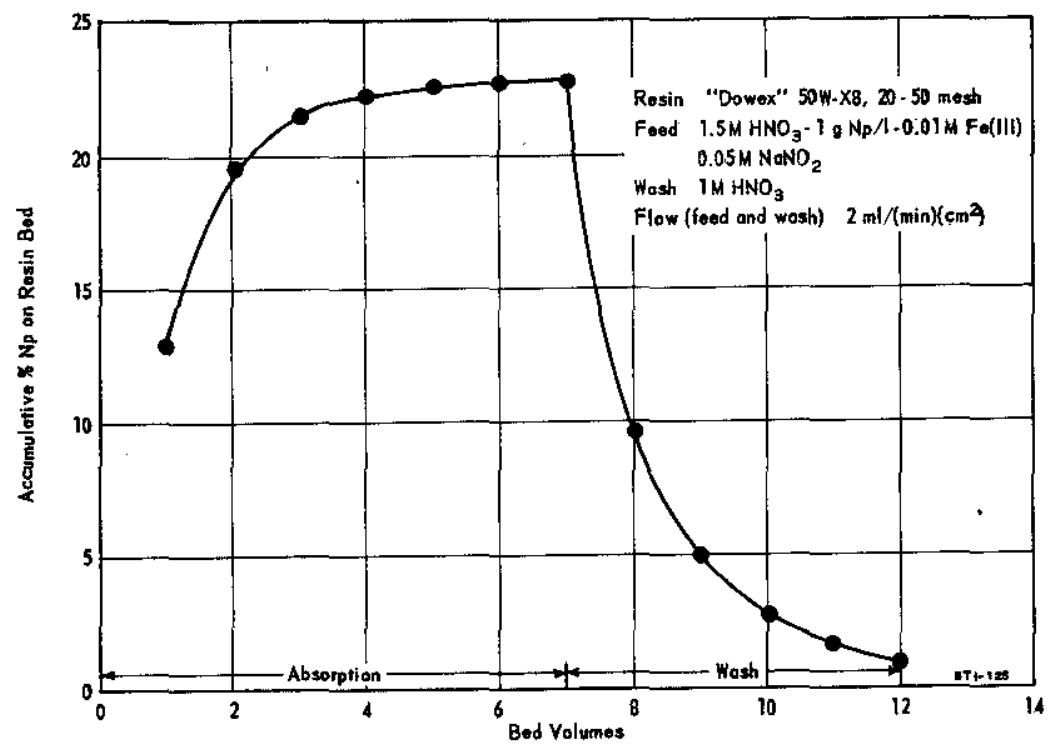

FIG. 5 SEPARATION OF THORIUM AND NEPTUNIUM BY CATION EXCHANGE

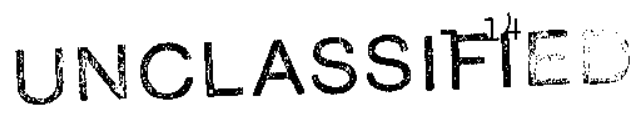




\section{UMCLASSIFIED}

The satisfactory performance of the cation exchange cycle is demonstrated by the typical results given in Table IV. In addition to the satisfactory separation from thorium and the adequate recovery of neptunium, an appreciable separation from $\mathrm{Zr}^{95}-\mathrm{Nb}^{95}$ was achieved.

TABLE IV

Performance of Cation Exchange Cycle Factor for separation from fision products: 3 to 10

\begin{tabular}{|c|c|c|c|c|c|c|c|c|c|c|c|c|}
\hline \multirow[b]{2}{*}{ cycle step } & \multirow{2}{*}{$\begin{array}{l}\text { Volume, } \\
\text { bed } \\
\text { volumes }\end{array}$} & \multirow{2}{*}{$\begin{array}{c}\text { Plow, } \\
\text { ml } \\
\text { min })\left(\mathrm{cm}^{2}\right)\end{array}$} & \multicolumn{7}{|c|}{ Composition } & $\begin{array}{r}\text { Effluent } \\
\not 6 \text { of } \\
\text { Fed } \\
\end{array}$ & \multicolumn{2}{|c|}{$\begin{array}{l}\text { Composition, } \\
\text { Amount } \\
\text { to Cycle }\end{array}$} \\
\hline & & & $\begin{array}{c}\mathrm{HNO}_{3} \\
\mathrm{M}\end{array}$ & $\begin{array}{c}\text { Fe(111), } \\
M\end{array}$ & $\begin{array}{c}\mathrm{NaNO}_{2}, \\
\mathrm{M}\end{array}$ & $\mathrm{Np}, 1$ & $\mathrm{gu}, \mathrm{i}$ & In, & $\begin{array}{c}\mathrm{NaHSO}_{4}, \\
\end{array}$ & $\mathrm{~Np}$ & $\mathrm{Pu}$ & Th \\
\hline Feed absorption & 4.5 & 2 & $1-2$ & 0.01 & 0.05 & 1.7 & 0.01 & 0.36 & - & 75 & $10-75$ & $<0.5$ \\
\hline Neptunfum wash & $4-5$ & 2 & $0.5-1$ & $\rightarrow$ & - & - & - & - & - & $23-25$ & $<1$ & $<0.5$ \\
\hline Thorlum elution (a) & 8 & 0.5 & - & - & - & - & - & - & 1 & $1-2$ & $25-90$ & $>99$ \\
\hline
\end{tabular}

(a) As required

Thorium was eluted satisfactorily from "Dowex" $50 \mathrm{~W}-\mathrm{X} 8$ resin with IM NaHSO${ }_{4}$. About $60 \%$ more elutriant was required with $20-50$ mesh resin than with 50-100 mesh (Figure 6). Elution with 4.5M HNO 3 was much less effective (Figure 7). Increasing the concentration of nitric acid to $6 \mathrm{M}$ or the temperature of elution to $55^{\circ} \mathrm{C}$ did not improve the efficiency.

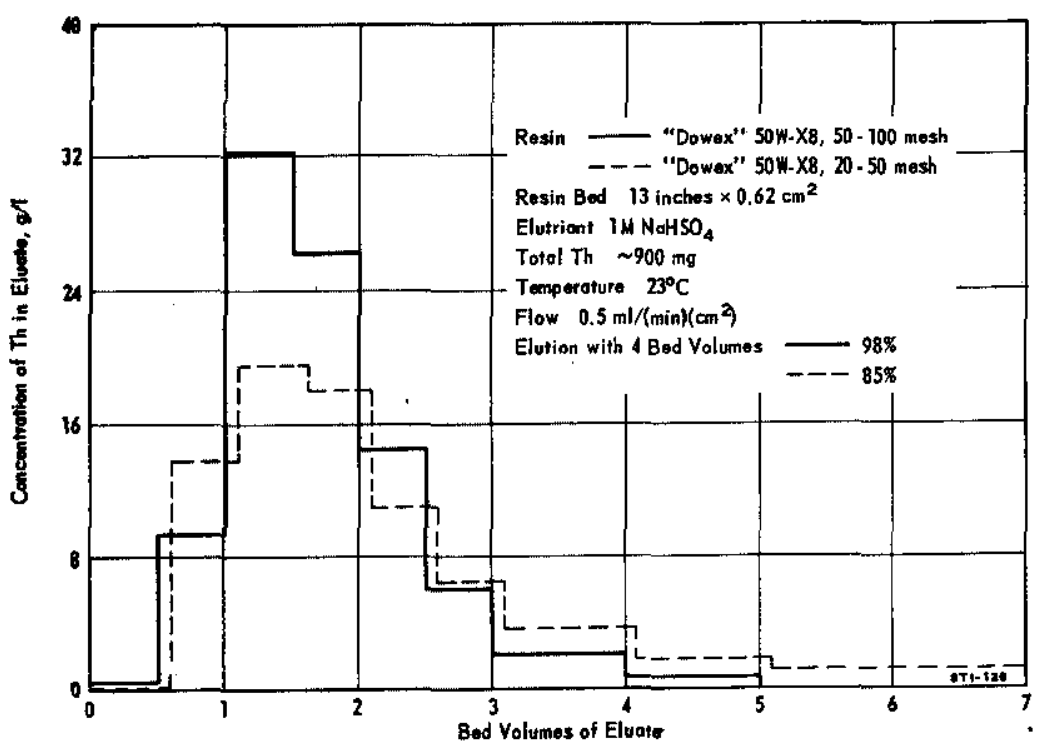

FIG. 6 ELUTION OF Th(IV) FROM CATION RESIN WITH SODIUM BISULFATE

\section{UNCLASSIFIED}




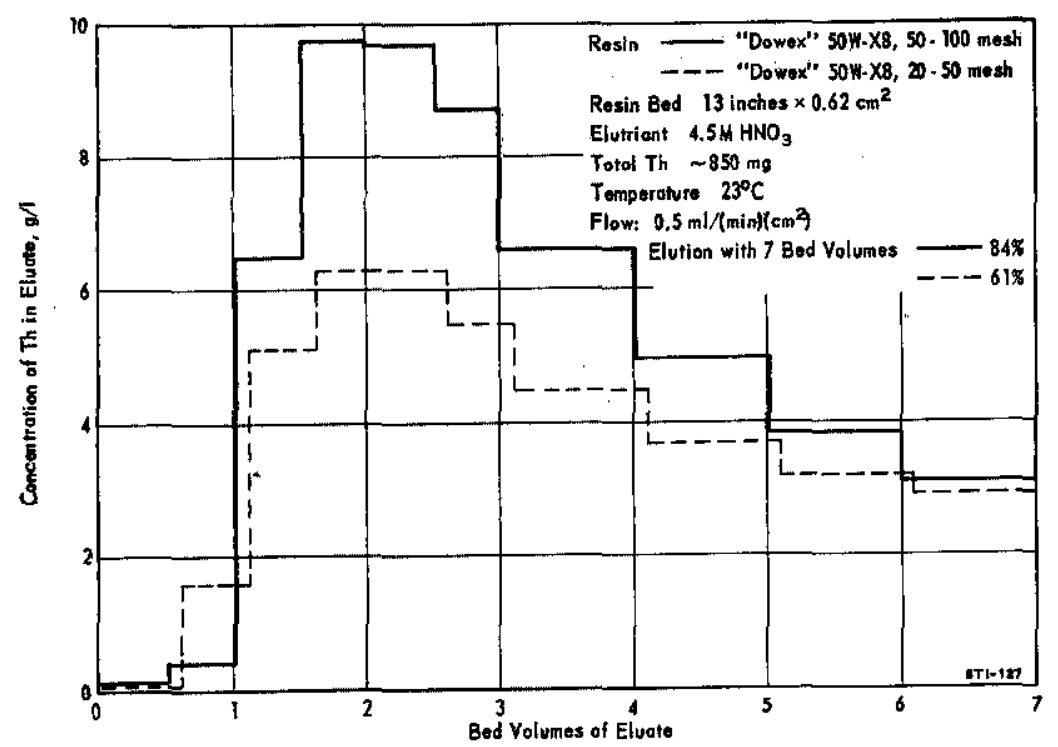

FIG. 7 ELUTION OF Th(IV) FROM CATION RESIN WITH NITRIC ACID

\section{OVER-ALL PERFORMANCE OF PROCESS}

The recovery of neptunium and the separations achieved over the three cycles of ion exchange were as follows:

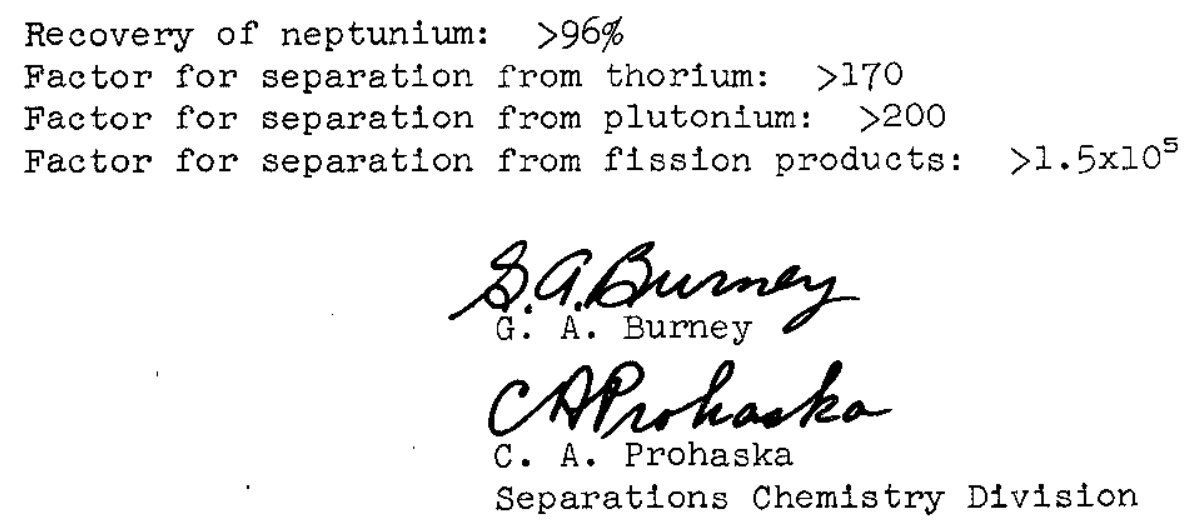

U.CLASSIFIED 


\section{liniri ASCIFIER}

\section{BIBLIOGRAPHY}

1. Snyder, M. D. Recovery of Neptunium from Purex Waste by Anion Exchange. E. I. du Pont de Nemours \& Co., Savannah River Laboratory, Alken, S. C. AEC Research and Development Report DP-742 (Secret) (to be issued).

2. Mottel, W. J. and J. F. Proctor. The Adaptation of an Ion Exchange Process to Remote Operation in a Radiochemical Separations Plant. E. I. du Pont de Nemours \& Co., Savannah RIver Laboratory, Alken, S. C. AEC Research and Development Report DP-620, 20 pp. (September 1961)(Secret).

3. Burney, G. A. and C. A. Prohaska. Recovery of $\mathrm{Np}^{237}$ and $\mathrm{Pu}^{238}$ from Irradiated Neptunium Oxide. E. I. du Pont de Nemours \& Co., Savannah River Laboratory, Alken, S. C. AEC Research and Development Report DP-417, 14 pp. (November 1959)(Secret).

4. Ryan, J. L. Concentration and Final Purification of Neptunium by Anion Exchange. General Electric Co., Hanford Atomic Products Operation, Richland, Wash. AEC Research and Development Report HW-59.193 (Rev.), $18 \mathrm{pp}$. (September 1959).

5. Burney, G. A. Anion Exchange of Neptunium in Nitrate Solutions. E. I. du Pont de Nemours \& Co., Savannah River Laboratory, Aiken, S. C. AEC Research and Development Report DP-531, 20 pp. (December 1960)(Secret).

6. Burney, G. A. Separation of Neptunium and Plutonium by Anion Exchange. E. I. du Pont de Nemours \& Co., Savannah River Laboratory, Aiken, S. C. AEC Research and Development Report DP-689, 36 pp. (April 1962)(Secret).

7. Danon, J. "Adsorption of Thorium by Anion-Exchange Resins from Nitric Acid Media". J. Am. Chem. Soc. 78, 5953-4 (1956).

8. Ryan, J. L. and E. J. Wheelwright. The Recovery, Purification, and Concentration of Plutonium by Anion Exchange in Nitric Acid. General Electric Co., Hanford Atomic Products Operation, Richland, Wash. AEC Research and Development Report HW-55893, $104 \mathrm{pp}$. (January 1959).

9. Sullivan, J. C., D. Cohen, and J. C. Hindman. "The Behavior of Uranyl and Neptunyl Ions with Dowex-50 Cation-Exchange Resin". J. Am. Chem. Soc. 77, 6203-4 (1955).

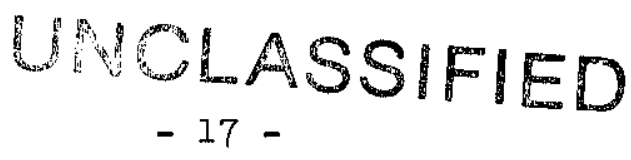

